\title{
IMPROVING STUDENTS' ACHIEVEMENT IN LEARNING CIRCLE LESSON OF MATHEMATICS BY GROUP WORK METHOD AT JUNIOR HIGH SCHOOL (SMPN) 4 LOA JANAN \\ Sukardi ${ }^{1}$ \\ ${ }^{1}$ SMPN 4 Loa Janan \\ Email: sukardipanca66@gmail.com
}

\begin{abstract}
The aim of the study was to investigate how the teaching method of group work could improve students' achievement in learning one of the mathematics lessons, the circle. A study about the use of group work method is expected to solve the problem faced by the teacher by a systematic thinking framework. Therefore the researcher collaborated with his peer to conduct the research. This classroom action research study was conducted at Junior High School (SMPN) 4 Loa Janan. The participants of the research were all the students from the eighth grade. The procedures of the study were conducting pretest, lesson planning for action research, implementing the lesson with proposed method, observing the lesson, reflection, and evaluation. The study was conducted in three cycles. The results showed that there was an improvement in students' mathematics academic achievement. This was proven by the students' test results from one cycle to another that the student scored significantly above $80 \%$ above minimum criteria
\end{abstract}

Keywords: Group Work, Mathematics Achievement.

\section{INTRODUCTION}

One of the lessons in mathematics subject in the eighth grade at Junior High School is the circle. This has become one part of the teacher's concern about the teaching for this material. The teacher is challenged about what method to employ, what approach, and how to make the students understand the lesson easily. The teaching of mathematics at SMPN 4 Loa Janan has been conducted in a conventional approach (Manoy, 2004). Furthermore, the facility for learning was very limited including the availability of student book. As a result, many students did not reach the passing grade for mathematics lesson.

According to Roger and Johnson (in Lie, 2002) not all group work can be included in cooperative learning. In order to get a maximum result, there are five aspects that should be implemented: active cooperation, personal responsibility, face to face communication and communication within the group. Sanjaya (2007) argued that in in a small group work discussion there should be at least 3-7 people and according to Nasution (2004) group work should include 
starting the unit, formulating the problem, analyzing the problem, discussing the problem solving, task splitting, working on the unit (collecting information, making report), closing the unit (conducting exhibition, submitting the report, and evaluating the unit). In group work, students learn how to be critical and creative. They learn how to solve problems, and identify their capability. Thus, the researcher was interested to conduct a study of classroom action research about improving students' mathematics achievement by using group work approach. Some of the factors that motivate the researcher in conducting this classroom action research utilizing group work method were because group work could trigger active participation and plant the positive moral values such as teamwork, appreciating others' opinion, and organizing works through working with others.

\section{METHOD}

This classroom action research was conducted in even semester at SMPN 4 Loa Janan. The participants of the research were all the students from the eighth grade with total 23 students (Depdiknas, 2005). This study employed the model as proposed by Kemmis \& Taggart with the cycle stages: planning, acting, observing, and reflecting. The data was taken from (1) the test and the group work results in each cycle. (2) Documentation/Observation from the process of teaching and learning. The data was analyzed with data reduction technique: data reduction, presentation, conclusion (Miles \& Huberman in Depdiknas, 2008). The data were then presented in description, tables, and charts.

\section{FINDINGS AND DISCUSSION}

In the first cycle, the lesson planning was made and the plan was for one meeting with the duration 2x40 minutes. The execution of the first meeting, with the focus of the lesson was the properties of the circles and circumference. The lesson was started by reading the materials on mathematics book of Junior high school (Adinawan \& Sugijono, 2005). As it was initial activity, the teaching approach was by using lecturing, Q\&A, demonstration, and task split. From the observation of the first action, it could be identified that the teacher did not appreciate the lesson very well. The students did not fully get involved. During the teaching process the teacher did not engage the students and had less monitoring activity. Perhaps this was due to the observation process that the teacher still felt shy being observed. As the result, the teacher did not sound very clear that the students had difficulty to pay attention. Afterwards, the teacher reinforced the 
materials and the students were asked to write them down and conclude the lesson given by the teacher.

The second meeting was conducted a week after the previous one. The teacher continued the lesson with the learning material about determining the value of phi $(\pi)$ as suggested by the students book added with some examples from the teacher. The teaching approach was with demonstration, Q\&A, and group work. The note from observation showed that the teacher could focus more, as the students got more engaged with the learning activity. After the students understand the lesson, the teacher asked the students to work in group on the comparison table of the circumference, and diameter of a circle made by the teacher.

The third meeting was conducted in the following week. In this meeting the teacher taught the lesson about the approach of the phi ( $\pi$ ) value as presented in the students book (Nuharini, 2008). The teacher explained the variation of phi value such as $\pi=\frac{22}{7}$ atau $\pi=3,14$ as well as how to use it and the examples of each use. The approach used was expository, Q\&A, and group task. The teacher gave some examples and asked the students to work on the exercise with their peers in group work. At the end of the meeting, a test was given to the students individually. The aim of the test was to become the initial evaluation to seek the problem and obstacles of the students in understanding the lesson (learning materials) presented by the teacher. The observation was conducted in all meetings as explained in above paragraph. The observation was done by peer math teacher and the school principal. Based on the observation there were some students who did not understand the lesson very well. They were (name initial) AP, AF, EL, and JH. Quantitatively, the result of the students' academic achievement on circumference did not reach $80 \%$. This means that the first cycle had not met the criteria of success. Therefore, the second cycle was necessary.

The process was repeated; learning from previous cycle, the teacher prepared the lesson plan for teaching the students about the materials related to circumference, the formula of circumference, and the use of circumference calculation in daily life. The orientation of the learning process was on the students thinking process development. The researcher worked with his peer and the school principal looking at how the math teacher taught the class in every meeting. On the fourth meeting, the lesson was conducted with the focus of the lesson about the circumference, the computation of circumference and the use of it in daily life. The next meeting was conducted a week after that. In the fifth meeting the teacher continued teaching the lesson and gave a test which was prepared by the researcher and the teacher. On the sixth meeting, the 
teacher delivered the lesson related to the circumference on the shaded circle. The teacher used some approaches like expository, Q\&A, and group work task and then the learning activity is followed by an exercise. At the end of the class the teacher asked the students to prepare the lesson about how to determine the area of the circle. They were also asked to bring rulers, scissor, glue, and carton paper. The observation was conducted for the second cycle (cycle II) and followed by a reflection. The result of the second cycle showed that the teacher had conducted the teaching and learning process accordingly and he also helped the students working on the task.

On the third cycle (cycle III) the researcher and the teacher prepared the lesson plan and the supporting demonstration tools for learning the material about the area of circle and the circumference as well as the use of the lesson in daily life. As planned, the lesson was conducted in three meetings. The teaching process was oriented to the students' development thinking process at SMPN 4 Loa Janan. The researcher who is also a math teacher observed the learning process in every meeting. The seventh meeting was conducted by the teacher delivering the lesson about determining the area of circle. The observation note showed that the teacher had taught the students with the concern of students' development thinking process and the students had worked in group. In the eighth meeting, the class continued to the lesson about how to calculate the area of circle. The teacher notified the students to get ready for an evaluation test on circumference and the area of circle. The $9^{\text {th }}$ meeting was conducted to take the score of the students through the test. In this stage the observation on the teacher teaching was not conducted as there was no teaching process. The data taken on the ninth meeting was the score of the students from the test.

From the observation on the teaching and learning process during the classroom action research conducted by the math teacher at SMPN 4 Loa Janan, it can be concluded that the teacher had conducted the process according to the plan.

From the finding on the observation and the test result the researcher could conclude that the method of group work in teaching the lesson of circle to the students of eighth grade at SMPN 4 Loa Janan could improve the students' academic achievement. According to Miles \& Huberman in Depdiknas (2008), the data collected in action research can be presented in description and or table/diagram. The following was the result of the reflection and observation during the classroom action research: 
Table 4.1. The Result of Observation and Reflection

\begin{tabular}{|c|c|c|c|}
\hline No & Date & $\begin{array}{l}\text { Subject } \\
\text { Object }\end{array}$ & $\begin{array}{l}\text { The Result of Observation and Reflection in the } \\
\text { Research }\end{array}$ \\
\hline \multirow[t]{3}{*}{1} & $\begin{array}{l}19 \text { February } \\
2014\end{array}$ & $\begin{array}{l}\text { Teacher } \\
\text { and } \\
\text { students }\end{array}$ & $\begin{array}{l}\text { In the initial activity, the teacher needed to attract and } \\
\text { guide the students by explaining the importance of the } \\
\text { current lesson and also described the implication for } \\
\text { daily application. }\end{array}$ \\
\hline & & teacher & $\begin{array}{l}\text { In concluding the lesson, it is suggested to involve the } \\
\text { students, not only rely on the teacher alone. }\end{array}$ \\
\hline & & $\begin{array}{l}\text { Teacher } \\
\text { and } \\
\text { students }\end{array}$ & $\begin{array}{l}\text { The students did not get a chance to think and to } \\
\text { express their opinion and they also did not have the } \\
\text { opportunity to ask questions. The students might not } \\
\text { have the correct answer but this was when a teacher } \\
\text { should function as a facilitator to guide them to the } \\
\text { correct answer. More importantly, the teacher should } \\
\text { not let down the students, act wisely to individual } \\
\text { students or groups. }\end{array}$ \\
\hline \multirow[t]{3}{*}{2} & $\begin{array}{l}05 \text { March } \\
2014\end{array}$ & $\begin{array}{l}\text { Teacher } \\
\text { and } \\
\text { students }\end{array}$ & $\begin{array}{l}\text { At the beginning of the lesson the teacher had already } \\
\text { attracted the students to the lesson. The teaching and } \\
\text { learning process had improved compared to the } \\
\text { previous cycle. This means that the mastery of the } \\
\text { lesson at this stage was better and showed } \\
\text { improvement in learning achievement. }\end{array}$ \\
\hline & & $\begin{array}{l}\text { Teacher } \\
\text { and } \\
\text { students }\end{array}$ & $\begin{array}{l}\text { The teacher had tried to involve the student in } \\
\text { concluding the lesson. }\end{array}$ \\
\hline & & $\begin{array}{l}\text { Teacher } \\
\text { and } \\
\text { students }\end{array}$ & $\begin{array}{l}\text { The teacher should reinforce the students answer. Thus, } \\
\text { the students would not hesitate to get involved and } \\
\text { express their opinion. It also helped them to get the firm } \\
\text { answer from the teacher. }\end{array}$ \\
\hline 3. & $\begin{array}{l}18 \text { March } \\
2014\end{array}$ & $\begin{array}{l}\text { Teacher } \\
\text { and }\end{array}$ & $\begin{array}{l}\text { On delivering the lesson the teacher had improved the } \\
\text { teaching approach and succeeded to make the lesson }\end{array}$ \\
\hline
\end{tabular}




\begin{tabular}{ll}
\hline students & $\begin{array}{l}\text { more interesting. The teacher explained the use of the } \\
\text { knowledge in daily application and it attracted the } \\
\text { students' attention. }\end{array}$ \\
\hline Teacher & The students concluded the materials by themselves and \\
and & the teacher helped if there was any mistaken by the \\
students & students. \\
& The teacher encouraged the students to participate \\
& actively in the learning activity and reinforce the \\
students' answers towards the received lesson.
\end{tabular}

The following chart showed the mean score of each cycle about the students' academic achievement on learning mathematic lesson, the circle, at SMPN 4 Loa Janan.

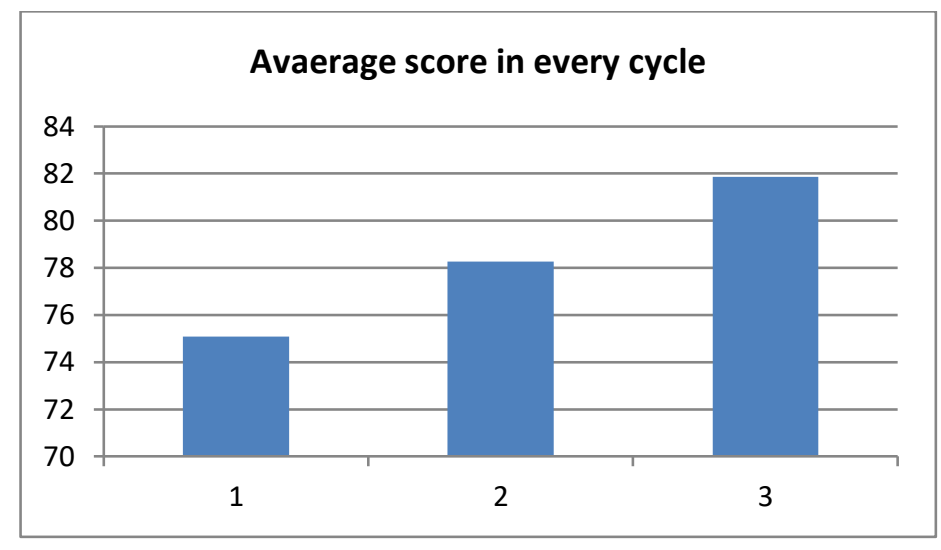

Chart 1. Mean score of the students in each cycle.

\section{CONCLUSIONS}

The results have showed that the percentage of the learning process had reached $80 \%$. It means that the action research on improving the students' academic achievement by using group work approach had succeeded. The lesson taught in the learning process was about the circle, how to calculate the area, the circumference, and the application in daily life. Therefore, the researcher could conclude that the students' mathematic achievement of the eighth graders at SMPN 4 Loa Janan could improve by using group work approach.

Some points of conclusion were also proposed in the following points: 
- The teacher should have a reflection in order to identify the problem in the learning process and then find the solution of the problems. By doing a reflection the teacher could also identify the weaknesses he/she possesses that later it can be a medium for improvement.

- The teacher would realize the weakness when he/she is observed by his/her peers or other researcher. This process does not mean that the teacher was going to be blame for the weakness instead it should be a motivation for the teacher to develop to be better.

- The students who did not answer the question correctly could be identified after the result had released, studied, and observed.

- Group work method/approach is one of the efforts to improve students' mathematic academic achievement.

- The success of the academic achievement should be set from the parameter of national competency standard and basic competency.

As it was already proven that the group work could help improve the students' achievement in learning the circle, it is also suggested to be applied in other mathematic lessons.

\section{REFERENCES}

Adinawan, M. Cholik \& Sugijono. (2005). Matematika Untuk SMP/MTs Kelas VIII. Jakarta: Erlangga.

Depdiknas. (2005). Materi Pelatihan Terintregrasi Matematika Buku 1, 2 dan 3. Jakarta: Depdiknas DirJenDasmen Direktorat Pendidikan Lanjutan Pertama.

Depdiknas. (2008). Pengolahan dan Analisis Data. Jakarta: Depdiknas DirJenDasmen Direktorat Pendidikan Lanjutan Pertama

Kurikulum Tingkat Satuan Pendidikan. (2005). Silabus Pengajaran Sekolah Lanjutan Tingkat Pertama (SLTP) Mata Pelajaran Matematika Kelas VIII. Jakarta: Departemen Pendidikan Nasional.

Lie, A. (2002). Cooperative Learning.Mempraktikkan Cooperative Learning di Ruang-Ruang Kelas. Jakarta: PT Gramedia Widiasarana Indonesia.

Manoy, Janet Trineke. (2000). Efektivitas Model Pembelajaran Diskusi Untuk Matematika Pokok Bahasan Lingkaran I di Kelas II SLTP. Tesis. Surabaya: Program Pascasarjana Universitas Negeri Surabaya.

Nasution, S. (2004). Didaktik Asas-asas Mengajar. Jakarta: PT Bumi Aksara.

Nuharini, Dewi (2008). Matematika Konsep dan Aplikasinya untuk Kelas VIII SMP/MTs. Jakarta: Pusat Perbukuan Departemen Pendidikan Nasional 
Peraturan Menteri Pendidikan Nasional RI. (2006). Standar Kompetensi Lulusan Untuk Satuan Pendidikan dan Menengah. Jakarta: Departemen pendidikan Nasional

Sanjaya, Wina. 2012. Strategi Pembelajaran (Berorientasi Standar Proses Pendidikan). Jakarta: Kencana. 